NOTE

\title{
MS-222 (tricaine methane sulfonate) does not kill the amphibian chytrid fungus Batrachochytrium dendrobatidis
}

\author{
Rebecca Webb*, Lee Berger, Diana Mendez, Rick Speare \\ Amphibian Disease Ecology Group, School of Public Health, Tropical Medicine and Rehabilitation Sciences, \\ James Cook University, Townsville, Queensland 4811, Australia
}

\begin{abstract}
MS-222 (tricaine methane sulfonate) is an agent commonly used to anaesthetise or euthanize amphibians used in experiments. It is administered by immersing the animal to allow absorption through the skin. Chytridiomycosis is an important disease of amphibians and research involves experiments with live animals. Batrachochytrium dendrobatidis, the fungus which causes chytridiomycosis, is located in the skin and therefore the organism should come into contact with MS-222 when it is used. B. dendrobatidis is a sensitive organism which could possibly be killed by MS-222. Hence, results of chytridiomycosis studies in which MS-222 is used could be unreliable. A concentration of $2 \mathrm{~g} \mathrm{l}^{-1}$ and an exposure duration of $1 \mathrm{~h}$ is at the high end of the range at which MS-222 would be most commonly used. Exposure to $2 \mathrm{~g} \mathrm{l}^{-1} \mathrm{MS}-222$ for $1 \mathrm{~h}$ does not kill B. dendrobatidis cultures, suggesting that MS-222 is safe to use in chytridiomycosis studies.
\end{abstract}

KEY WORDS: MS-222 • Tricaine methane sulfonate • Batrachochytrium dendrobatidis · Chytridiomycosis $\cdot$ Anaesthetic

Resale or republication not permitted without written consent of the publisher

Chytridiomycosis is infection with the amphibian chytrid fungus Batrachochytrium dendrobatidis (Berger et al. 1998, Longcore et al. 1999). In susceptible amphibian species, the mortality rate can approach $100 \%$ (Berger et al. 2004). In vitro experimental infections have played an important role in understanding chytridiomycosis (Nichols et al. 2001). To minimise pain and distress due to handling and sampling of amphibians used for experimental studies, MS-222 (tricaine methane sulfonate) is recommended as an anaesthetic. Concentrations of 1 to $1.5 \mathrm{~g} \mathrm{l}^{-1}$ with an exposure time of up to $30 \mathrm{~min}$ is sufficient for adult anuran anaesthesia (Kaplan 1969, Poole 1987, Arena \& Richardson 1990, Wright 2001). A higher concentration $\left(2 \mathrm{~g} \mathrm{l}^{-1}\right)$ for longer periods of time can be used for euthanasia (Poole 1987). Lower concentrations are required for urodele anaesthesia and euthanasia (Arena \& Richardson 1990). MS222 is an aqueous solution in which amphibians are totally immersed and the duration of exposure is modified depending on the response of the amphibian and effect desired. During absorption through the skin, MS222 must come into contact with the zoosporangia of $B$. dendrobatidis which are located only in the stratum corneum and stratum granulosum (Berger et al. 1998).

There is a range of chemicals that can cause $100 \%$ mortality of Batrachochytrium dendrobatidis (Johnson et al. 2003). There are no data available on the antifungal properties of MS-222. We were concerned that if MS-222 had a killing effect on $B$. dendrobatidis, the results obtained in amphibians with experimental chytridiomycosis either anaesthetised or killed by MS222 would be adversely affected. We therefore evaluated the killing effect of MS-222 on B. dendrobatidis.

MS-222 was tested using $4 \mathrm{~d}$ old cultures of Batrachochytrium dendrobatidis in 96-well flat bottom plates, each well having initially contained $8 \times 10^{4} \mathrm{zoo}-$ 
spores, as per Johnson et al. (2003). The MS-222 was buffered to neutral with $\mathrm{Na}_{2} \mathrm{HPO}_{4}$ and the cultures were exposed to a range of concentrations and durations, the highest being $2 \mathrm{~g} \mathrm{l}^{-1}$ for $1 \mathrm{~h}$. None of the treatments caused $100 \%$ mortality of the B. dendrobatidis cultures. In the case of the $2 \mathrm{~g} \mathrm{l}^{-1}$ for $1 \mathrm{~h}$ treatment, all 8 replicate wells contained active cultures by $5 \mathrm{~d}$ after exposure.

This result proves that, at the concentrations most commonly used, MS-222 will not kill Batrachochytrium dendrobatidis. This result is significant as it allows the results of past and future experiments on chytridiomycosis in which MS-222 has been used to be viewed with confidence, and encourages the humane treatment of experiment amphibians.

Acknowledgements. This study was funded by the Department of Environment and Heritage (Australia) tender RFT 63/2003.

\section{LITERATURE CITED}

Arena PC, Richardson KC (1990) The relief of pain in coldblooded vertebrates. ACCART News 3:1-4

Editorial responsibility: Peernel Zwart, Utrecht, The Netherlands
Berger L, Speare R, Daszak P, Green DE and 10 others (1998) Chytridiomycosis causes amphibian mortality associated with population declines in the rain forests of Australia and Central America. Proc Nat Acad Sci USA 95: 9031-9036

Berger L, Speare R, Hines H, Marantelli G and 10 others (2004) Effect of season and temperature on mortality in amphibians due to chytridiomycosis. Aust Vet $\mathrm{J}$ 82: 31-36

Johnson M, Berger L, Philips L, Speare R (2003) Fungicidal effects of chemical disinfectants, UV light, desiccation and heat on the amphibian chytrid Batrachochytrium dendrobatidis. Dis Aquat Org 57:255-260

Kaplan HM (1969) Anesthesia in amphibians and reptiles. Proc Fed Am Soc Exp Biol 28:1541-1546

Longcore JE, Pessier AP, Nichols DK (1999) Batrachochytrium dendrobatidis gen. et sp. nov., a chytrid pathogenic to amphibians. Mycologia 91:219-227

Nichols DK, Lamirande EW, Pessier AP, Longcore JE (2001) Experimental transmission of cutaneous chytridiomycosis in dendrobatid frogs. J Wildl Dis 37:1-11

Poole TB (1987) The UFAW handbook of the care and management of laboratory animals, 6th edn. Longman Scientific and Technical, Harlow

Wright KM (2001) Restraint techniques and euthanasia. In: Wright KM, Whitaker BR (eds) Amphibian medicine and captive husbandry. Krieger Publishing, Malabar, FL, p 111-112

Submitted: August 25, 2005; Accepted: November 3, 2005 Proofs received from author(s): December 23, 2005 